\title{
Pengelolaan Wakaf Produktif Tanah Sawah Di Yayasan Islam Pondok Pesantren Miftahul Jannah Jatibaru Kecamatan Jatisari Karawang
}

\author{
Tetep Komarudin ${ }^{1}$, Ahmad Damiri ${ }^{2}$, Jalaludin ${ }^{3}$ \\ ${ }^{1}$ KUA Kotabaru Cikampek Karawang \\ ${ }^{2}$ UIN Sunan Gunung Djati Bandung \\ ${ }^{3}$ STIE Syariah Indonesia Purwakarta \\ Jl. Veteran No 150-152 Purwakarta 41118 Jawa Barat Indonesia \\ ${ }^{1}$ tetepkomarudin@gmail.com \\ ²ahmad.damiri86@gmail.com \\ 3jalaludin@sties-purwakarta.ac.id
}

\begin{abstract}
Abstrak- Tujuan dari penelitian ini adalah untuk mengetahui bagaimana sistem pengelolaan wakaf produktif tanah sawah di Yayasan Islam Pondok Pesantren Miftahul Jannah Jatibaru Kecamatan Jatisari Karawang, dan bagaimana penyaluran hasil dari pengelolaan wakaf produktif tanah sawah di Yayasan Islam Pondok Pesantren Miftahul Jannah. Jenis penelitian yang digunakan adalah penelitian lapangan (field research), adapun pendekatan yang digunakan dalam penelitian ini adalah pendekatan deskriptif-kualitatif. Nadzir sebagai pengelola wakaf dalam rangak melindungi aset harta wakaf, nadzir melakukan pembuatan Akta Ikrar Wakaf (AIW) ke PPAIW supaya mempunyai kekuatan hukum sesuai dengan peraturan perundang-undangan. Nadzir dalam mengelola wakaf tanah sawah dengan cara disewakan dan dalam penentuan penyewaannya menggunakan sistem sewa pertahun (model sewa jangka panjang dan hukr), dalam prinsip pembayarannya secara langsung atau tunai untuk jangka waktu satu tahun. Pengelola wakaf belum pernah melaporkan pengelolaan wakaf kepada pihak pemerintah atau pihak terkait dikarenakan tidak mengerti jalur atau tata cara pelaporannya. Dalam pola pengelolaannya masih termasuk dalam pola pengelolaan wakaf tradisional konsumtif. Hasil dari pengelolaan wakaf tanah sawah di peruntukan untuk operasional pondok pesantren dan untuk perbaikan atau renovasi ringan di pondok pesantren, dengan pembagian $50 \%$ untuk perbaikan atau renovasi ringan pondok pesantren dan $50 \%$ untuk biaya operasional pondok pesantren. Biaya operasional dibagi diperuntukannya $75 \%$ untuk honor dewan guru dan $25 \%$ untuk kebutuhan Alat Tulis Kantor.
\end{abstract}

Kata Kunci: Pengelolaan, Wakaf Produktif Tanah Sawah.

Abstract - The purpose of this researech is to find out how the productive waqf management system of paddy land at the islamic fondation Miftahul Jannah Islamic Boarding School in Jatibaru District Jatisari Karawang, and how the distribution of results from productive waqf management of paddy land at the islamic fondation Miftahul Jannah Islamic Boarding School. Type of research used is field research, us for the approach used in this study is a descriptive-qualitative approach. Nadzir as the manager of waqf in the form of protecting waqf assets, nadzir made the Akta Ikrar Wakaf (AIW) to PPAIW so that have legal power in accordance with statutory regulation. In its management, nadzir uses the anual rental system (long-term rental model and hukr), in principle the payment is direct or cash for year. Waqf manager has never reported the management of waqf to the government or related parties because it does not understand the path or procedures for reporting. Management pattern is still included in the traditional consumptive waqf management pattern. The results of the management of waqf land are approved for boarding operation and for boarding improvements or revairs in school hostels, with a $50 \%$ share for the repairs or renovations of boarding schools and $50 \%$ for operational costs. Operational cost are divided $75 \%$ for the honorarium of the teacher council and $25 \%$ for the need of the Office Stationery.

Key Words: Management, Productive Wakaf Paddy Land

Tetep Komarudin |Pengelolaan Wakaf Produktif ....... 1 


\section{PENDAHULUAN}

Wakaf adalah perbuatan hukum seseorang atau kelompok orang atau badan hukum yang memisahkan sebagian dari benda miliknya dan melembagakannya untuk selama-lamanya guna kepentingan ibadah atau keperluan lainnya sesuai dengan ajaran Islam. (Departemen Agama RI, 1992) Dengan demikian wakaf merupakan istilah keagamaan, hal ini selain sebagai pengabdian diri kepada Allah juga berfungsi untuk memelihara rasa sosial sesama umat.

Dari perspektif ini wakaf termasuk dalam kelembagaan bisnis yang profit oriented. Selanjutnya terkait pula dengan keuntungan hasil pengelolaan harta benda wakaf tersebut tanpa timbal balik kepada mauquf 'alih. Biasanya ini berkaitan dengan layanan sosial, pengelolaan seperti ini termasuk dalam kategori yayasan sosial yang tidak profit oriented.

Hampir semua rumah ibadah, madrasah, perguruan tingi Islam dan lembaga keagamaan Islam dibangun di atas tanah wakaf. Dalam sejarah Indonesia, wakaf telah dikenal dan dilaksanakan oleh umat Islam sejak agama Islam masuk di Indonesia. Sebagai suatu lembaga Islam, wakaf telah menjadi salah satu penunjang perkembangan masyarakat. Jumlah tanah wakaf di Indonesia sangat banyak.

Menurut data Kementerian Agama Republik Indonesia terakhir terdapat 360.062 lokasi tanah wakaf dengan luas 48.529,22 Ha, antara lain yaitu masjid 44.88\%, Musholla 26,11\%, Sekolah $10.52 \%$, Pesantren 3,32\%, Makam $4.55 \%$ dan sosial lainnya $8.51 \%$. (Departemen Agama RI, 1992)

Wakaf produktif, yaitu wakaf harta yang digunakan untuk kepentingan produksi, baik dibidang pertanian, perindustrian, perdagangan dan jasa yang manfaatnya bukan pada benda secara langsung, tetapi dari keuntungan bersih hasil pengembangan wakaf yang diberikan kepada orang-orang yang berhak sesuai dengan tujuan wakaf. Di sini, wakaf produktif diolah untuk dapat menghasilkan barang atau jasa kemudian dijual dan hasilnya dipergunakan sesuai dengan tujuan wakaf (Departemen Agama RI, 1992).
Peraturan pemerintah yang sampai saat ini dijadikan landasan perwakafan tanah milik untuk kepentingan agama Islam Selanjutnya disempurnakan dalam Undang-Undang No. 41 Tahun 2004 tentang wakaf, yang memberikan ruang lingkup yang lebih luas terhadap perkembangan praktik perwakafan di Indonesia yang kemudian disusul dengan diterbitkannya PP No. 42 Tahun 2006. Kemudian dilanjutkan dengan dibentuknya Badan Wakaf Indonesia (BWI) sebagai lembaga yang berdiri secara independen dan secara khusus mengurus tentang perwakafan yang ada di Indonesia. Pelaksanaan wakaf secara produktif telah di atur dalam pasal 43 ayat (2) UU No. 41 Tahun 2004 tentang wakaf yang berbunyi "Pengelolaan dan pengembangan harta benda wakaf dilakukan secara produktif". Penjelasan dari pasal tersebut berbunyi :

"Dengan cara pengumpulan, investasi, penanaman modal, produksi, kemitraan, perdagangan, agrobisnis, pertambangan, perindustrian, pengembangan teknologi, pembangunan gedung, apartemen, rumah susun, pasar swalayan, pertokoan, perkantoran, sarana pendidikan, sarana kesehatan, dan usaha yang tidak bertentangan dengan syari'ah".

Didalam pengelolaannya wakaf produktif terdapat pembiayaan, baik dalam model pembiayaan proyek wakaf produktif secara tradisional maupun institusional.(Mundzir Qahaf, 2005) Salah satu contohnya praktek pengelolaan pembiayaan wakaf produktif yang ada di Yayasan Islam Pondok Pesantren Miftahul Jannah.

Penulis memilih Yayasan Islam Pondok Pesantren Miftahul Jannah sebagai objek penelitian karena Pondok Pesantren Miftahul Jannah adalah salah satu pesantren dari 14 pesantren yang ada di Kecamatan Jatisari Kabupaten Karawang dan merupakan pondok pesantren yang paling maju dibandingkan dengan pesantren yang lain, dan pengelolaan tanah wakaf yang ada di Yayasan Islam Pondok Pesantren Miftahul Jannah bisa dibilang cukup besar, dari data yang penulis himpun sendiri, luas tanah wakaf yang ada yaitu sebanyak $19.050 \mathrm{~m} 2$ yang terdiri dari tanah sawah $14.200 \mathrm{~m} 2$ dan tanah darat 4.850 m2. (Departemen Agama RI, 1992) 


\section{EKSISBANK Vol. 4 No. 1 Juni 2020}

Pondok Pesantren Miftahul Jannah merupakan tanah wakaf dari masyarakat yang sukarela mewakafkan tanahnya untuk mengembangkan pesantren. Adapun hasil dari wakaf tersebut di peruntukan untuk operasional pesantren dan kesejahtraan guru pesantren (Kementerian Agama RI, 2013).

Dengan terbentuknya lembaga Yayasan Islam Pondok Pesantren Miftahul Jannah, perkembangan praktik perwakafan yang mempunyai nilai produktifitas yang tinggi. Seperti halnya praktik perwakafan dalam Pengelolaan dan pengembangan wakaf produktif di Yayasan Islam Pondok Pesantren Miftahul Jannah akan pentingnya peranan tanah wakaf yang dimiliki untuk di kembangkan menjadi wakaf yang lebih produktif. Hal ini dapat dilihat dengan adanya tindakan yang dilakukan Pengasuh dan Pengurus Yayasan Islam Pondok Pesantren Miftahul Jannah tersebut yang berinisiatif untuk mengembangkan aset wakaf, yaitu ditandai dengan berdirinya SMP IT di sekitar pondok pesantren.

Beranjak dari fenomena tersebut maka penulis merasa tertarik meneliti lebih lanjut mengenai pengelolaan wakaf produktif yang beruapa tanah sawah yang ada di Yayasan Islam Pondok Pesantren Miftahul Jannah dengan mengangkat judul "Pengelolaan Wakaf Produktif Tanah Sawah Di Yayasan Islam Pondok Pesantren Miftahul Jannah Jatibaru Kecamatan Jatisari Karawang".

Wakaf secara bahasa berasal dari kata waqafayaqifu yang artinya berhenti, lawan dari kata istamâra. Kata ini sering disamakan dengan altahbîs atau al- tasbîl yang bermakna al-habs 'an tasarruf, yakni mencegah dari mengelola (Mundzir Qahaf, 2005).

Wakaf menurut istilah adalah penahanan harta yang diambil manfaatnya tanpa musnah seketika dan untuk penggunaan yang mubah serta dimaksudkan untuk mendapatkan ridho Allah SWT. (K.H. Ade Rosi Fauzan, 2019).

Sementara wakaf dalam Undang-Undang No. 41 Tahun 2004 tentang Wakaf, disebutkan bahwa wakaf adalah perbuatan hukum wakif untuk memisahkan atau menyerahkan sebagian harta benda miliknya untuk dimanfaatkan selamanya atau untuk jangka waktu tertentu sesuai dengan kepentingannya guna keperluan ibadah dan kesejahteraan umum menurut syariah. (Kementerian Agama RI, 2013)

Secara teks dan jelas wakaf tidak terdapat dalam Al-Qur'an dan Hadits, namun makna dan kandungan wakaf terdapat dalam dua sumber hukum Islam tersebut. Di dalam aturan sering menyatakan wakaf dengan ungkapan yang menyatakan tentang dema harta (infaq) demi kepentingan umum. Sedangkan dalam hadits sering kita temui ungkapan wakaf dengan ungkapan "tahan" (habs). (K.H. Ade Rosi Fauzan, 2019).

Landasan hukum al-Qur'an yang menjelaskan tentang wakaf terdapat dalam surat al-Baqarah: ayat 261 dan ali-Imran: ayat 92 . Sedangkan dalam Hadits yang menjadi dasar dan dalil wakaf adalah hadits yang menceritakan tentang kisah Umar bin Al-Khattab ketika memperoleh tanah di khaibar. Setelah ia meminta petunjuk Nabi tentang tanah tersebut, Nabi menganjurkan untuk menahan asal tanah dan menyedekahkan hasilnya.

Kata pengelolaan dapat disamakan dengan manajemen, yang berarti pula pengaturan atau pengurusan. Banyak orang yang mengartikan manajemen sebagai pengaturan, pengelolaan, dan pengadministrasian,dan memang itulah pengertian yang populer saat ini. Pengelolaan diartikan sebagai suatu rangkaian pekerjaan atau usaha yang dilakukan oleh sekelompok orang untuk melakukan serangkaian kerja dalam mencapai tujan tertentu.

Manajemen pengelolaan menempati posisi teratas dan paling urgen dalam mengelola harta wakaf. Karena wakaf itu bermanfaat atau tidak, berkembang atau tidak tergantung pada pola pengelolaan. Kita lihat saja pengelolaan wakaf yang ada sekarang ini, banyak sekali kita temukan harta wakaf tidak berkembang bahkan cenderung menjadi beban pengelolaan atau malah tidak terurus, manajemen berasal dari bahasa inggris: management dengan kata kerja to manage, diartikan secara umum sebagai mengurusi.

Sebagaimana dikutip Wadjdy dalam bukunya Stoner mengartikan manajemen sebagai proses perencanaan, pengorganisasian, pengarahan, dan pengawasan usaha para anggota organisasi 


\section{EKSISBANK Vol. 4 No. 1 Juni 2020}

dengan menggunakan sumber daya yang ada agar mencapai tujuan organisasi yang telah ditetapkan. (K.H. Ade Rosi Fauzan, 2019)

Produktif dalam arti bahasa yaitu banyak menghasilkan, bersifat mampu berproduksi. Manusia produktif secara definitif adalah kelompok entrepreneur yang berciri antara lain peka terhadap kebu-tuhan lingkungan sekelilingnya, menguasai informasi dan memiliki dinamika kreatifitas yang tinggi, sehingga mampu menciptakan bukan hanya mencari lapangan kerja, menumbuhkan wawasan ekonomi yang luas.

Wakaf produktif, yaitu wakaf harta yang digunakan untuk kepentingan produksi, baik dibidang pertanian, perindustrian, perdagangan dan jasa yang manfaatnya bukan pada benda secara langsung, tetapi dari keuntungan bersih hasil pengembangan wakaf yang diberikan kepada orang-orang yang berhak sesuai dengan tujuan wakaf. Di sini, wakaf produktif diolah untuk dapat menghasilkan barang atau jasa kemudian dijual dan hasilnya dipergunakan sesuai dengan tujuan wakaf.

Untuk mengelola wakaf produktif di Indonesia, yang pertama-tama adalah pembentukan suatu badan atau lembaga yang mengkoordinasi secara nasional bernama Badan Wakaf Indonesia. Badan Wakaf Indonesia (BWI) diberikan tugas mengembangkan wakaf secara produktif dengan membina Nadzir secara nasional, sehingga wakaf dapat berfungsi untuk meningkatkan taraf hidup masyarakat. Dalam pasal 47 ayat (2) disebutkan bahwa Badan Wakaf Indonesia (BWI) bersifat independen, dimana pemerintah dalam hal ini sebagai fasilitator.(Aden Rosadi, 2019)

Pengelolaan suatu perwakafan tidak dapat dipisahkan dari para nadzir. Hal ini disebabkan karena berkembang tidaknya harta wakaf, salah satu diantaranya sangat tergantung pada nadzir. Pengelolaan wakaf kelembagaan nadzir diberikan tugas sebagai berikutg: (K.H. Ade Rosi Fauzan, 2019)

1. Melakukan pengadministrasian harta benda wakaf.
2. Mengelola dan mengembangkan harta benda wakaf sesuai dengan tujuan, fungsi serta peruntukannya.

3. Mengawasi dan melindungi harta benda wakaf.

4. Melaporkan pelaksanaan tugas kepada BWI.

Model pembiayaan jaman sekarang ini tetap harus berdasarkan prinsip pembiayaan Islami yang dikenal baik. Dalam model pembiayaan harta wakaf tradisional, buku fikih klasik mendiskusikan lima model pembiayaan rekontruksi harta wakaf, yaitu: Pinjaman, $\mathrm{Hukr}$ (kon-trak sewa jangka panjang dengan pembayaran lump sum yang cukup besar dimuka), Al-Ijaratain (sewa dengan dua pembayaran), menambah harta wakaf baru dan penukaran pengganti (substitusi) harta wakaf. (Kementerian Agama RI, 2013) Dari kelima model ini hanya penambahan harta wakaf baru yang menciptakan penambahan pada modal wakaf dan peningkatan kepastian produksi. Sedang empat model yang lain banyak kepada membiayai operasional dan mengembalikan produktifitas semua harta wakaf.

Didalam pola pengelolaan wakaf di Indonesia ada dua paradigma yang pertama, paradigma lama terhadap pengelolaan wakaf, pengelolaan wakaf menekankan pada pentingnya pelestarian dan keabadian benda wakaf, paradigma ini menggunakan management tradisionalis konsumtif. Yang ke dua paradigma baru pengelolaan wakaf menekankan pada pemanfaatan yang lebih nyata tanpa kehilangan eksistensi benda wakaf, management yang dipakai pada paradigma ini yaitu professional produktif. (Aden Rosadi, 2019)

Adapun maksud dan tujuan dari penelitian ini adalah untuk mengetahui pengelolaan wakaf produktif tanah sawah di Yayasan Islam Pondok Pesantren Miftahul Jannah Jatibaru Kecamatan Jatisari Karawang dan untuk mengetahui penyaluran hasil dari pengelolaan wakaf produktif tanah sawah di Yayasan Islam Pondok Pesantren Miftahul Jannah Jatibaru Kecamatan Jatisari Karawang.

\section{METODE PENELITIAN}

Metode penelitian merupakan suatu ilmu yang membahas tentang cara bagaimana mendapatkan data untuk tujuan dan kegunaan tertentu. (Departemen Agama, 2005) Pada Penelitian ini metode penelitian yang digunakan adalah field research (penelitian lapangan), atau dapat pula 


\section{EKSISBANK Vol. 4 No. 1 Juni 2020}

dikatakan sebagai penelitian empiris atau sosiologis. Penelitian field research (penelitian lapangan) menitik beratkan pada hasil-hasil pengumpulan data yang didapatkan secara langsung di masyarakat, dari para informan atau nara sumber yang telah ditentukan.

Penelitian ini dilakukan di Yayasan Islam Pondok Pesantren Miftahul Jannah yang beralamat di Dusun Krajan 2 Rt 01/ Rw 02 Kaum Desa Jatibaru Kecamatan Jatisari Kabupaten Karawang. Adapun pendekatan yang digunakan dalam penelitian ini adalah pendekatan deskriptifkualitatif. Penelitian deskriptif adalah suatu penelitian yang bertujuan untuk membuat deskripsi atau gambaran atau lukisan secara sistematis mengenai suatu fenomena yang terjadi di masyarakat. (Kementerian Agama RI, 2013) Dalam penelitian ini, penulis menggambarkan sistem pengelolaan dan peruntukan hasil wakaf produktif di Yayasan Pondok Pesantren Miftahul Jannah.

Sumber data adalah hal yang paling utama dan juga yang paling penting dalam sebuah penelitian. Dilihat dari sumbernya pengumpulan data dapat menggunakan data primer dan data skunder. (Departemen Agama, 2005) Dalam penelitian ini sumber data yang diperoleh yaitu :

\section{Data Primer}

Merupakan data utama yang langsung diperoleh dari sumber utama. Dalam penelitian ini, sumber utamanya adalah mereka yang menjadi objek penelitian ini, yaitu wawancara langsung dengan Ketua Yayasan Pondok Pesantren Miftahul Jannah, Pengasuh Pondok Pesantren Miftahul Jannah, Dewan Guru Pondok Pesantren Miftahul Jannah dan penyewa wakaf tanah sawah.

\section{Data Sekunder}

Merupakan sumber data yang secara tidak langung memberikan data kepada pengumpul data (peneliti). Adapun data sekunder yang dijadikan peneliti sebagai bahan rujukan ialah literatur- literatur lain seperti al- Qur'an dan Hadits, buku-buku tentang pengelola wakaf, UU No. 41 Tahun 2004 tentang Wakaf, dan lain- lain yang berkaitan dengan skripsi ini.
Teknik pengumpulan data dalam penelitian ini meliputi observasi, Wawancara dan dokumentasi. Menurut Farid Wadjdy pengumpulan data dimaksudkan untuk menjelaskan urutan kerja atau sebagai alat dan cara untuk mengumpulkan data supaya data yang dihasilkan tersusun secara sistematis. (Farid Wadjdy dan Mursyid, 2007) Adapun teknik pengumpulan data pada penelitian ini ialah:

1. Observasi

Observasi ialah pengamatan dan pencatatan yang sistematis terhadap gejala-gejala yang diteliti. Observasi merupakan proses yang kompleks yang dimaksudkan untuk mengamati terhadap peristiwa-peristiwa yang dilakukan dengan cara melihat, mendengarkan, merasakan dan kemudian dicatat subyek penelitiannya. (Kementerian Agama RI, 2013) Selain itu, penulis melakukan observasi untuk mendapatkan gambaran mengenai kondisi obyektif realitas sosial baik berupa partisipasi maupun proses yang ada di lapangan. Dalam penelitian ini penulis turun ke lokasi penelitian secara langsung yaitu di Pondok Pesantren Miftahul Jannah.

2. Wawancara

Dalam sebuah penelitian kualitatif, wawancara adalah teknik atau metode pengumpulan data yang paling penting untuk mendapatkan data secara jelas dan terperinci. Wawancara dilakukan dengan cara tanya jawab secara langsung atau dengan kata lain antara penulis dan informan saling bertatap mata. Dalam penelitian ini, penulis akan mewawancarai para informan yang menjadi objek dari penelitian ini, sebagaimana yang telah disebutkan di atas. Secara garis besar, teknik atau metode pengumpulan data dengan cara wawancara ini terbagi menjadi dua macam, yaitu wawancara terstruktur dan wawancara tidak terstruktur: (Kementerian Agama RI, 2013).

Pengambilan informasi melalui wawancara dilakukan kepada informan 
EKSISBANK Vol. 4 No. 1 Juni 2020

dilakukan kepada Bapak K.H Ade Fauzan selaku Ketua Yayasan Pondok Pesantren Miftahul Jannah, Hj. Aisyah Maelasari selaku Pengasuh Pondok Pesantren Miftahul Jannah, H. Cecep Mahmud selaku Dewan Guru Pondok Pesantren Miftahul Jannah, Dan beberapa penyewa tanah wakaf sawah.

3. Dokumentasi

Dokumen merupakan catatan peristiwa yang sudah berlalu. Dokumen bisa berbentuk tulisan, gambar, atau karyakarya monumental dari seseorang. Studi dokumen merupakan pelengkap dari pengguna metode observasi dan wawancara dalam penelitian kualitatif. (Farid Wadjdy dan Mursyid, 2007) Data dokumentasi dalam penelitian ini bersumber dari data-data yang diperoleh dari arsip dan dokumentasi yang dimiliki Yayasan Pondok Pesantren Miftahul Jannah.

Berdasarkan hasil pengumpulan data yang telah terkumpul, maka proses selanjutnya adalah mengolah data. Tujuannya adalah agar memperoleh data yang terstruktur, baik, dan sistematis. Adapun tahapan-tahapan dalam pengolahan data adalah sebagai berikut:

1. Editing

Edit merupakan proses penelitian kembali terhadap catatan-catatan, berkas-berkas, dan informasi-informasi yang dikumpulkan oleh pencari data (peneliti). (Aden Rosadi, 2019) Berarti, dalam penelitian ini penulis kembali melakukan penelitian terhadap data-data yang diperoleh

2. Klasifikasi

Setelah proses edit selesai, maka proses pengolahan data selanjutnya adalah pengkalsifikasian atau pengelompokan data. Penulis akan mengelompokkan data yang diperoleh berdasarkan kategori tertentu sesuai dengan permasalahan yang ada. Tujuannya adalah supaya mempermudah proses pengolahan data selanjutnya, sehingga muatan dari penelitian ini dapat diterima dan dipahami dengan baik oleh pembaca.

3. Analisis

Selanjutnya penulis menganalisa data-data tersebut dengan cara membandingkan atau menambahi dengan teori-teori yang berhubungan dengan objek penelitian. Dengan proses ini, penulis akan menganalisa dan menyajikan data-data yang diperoleh dari lapangan baik dari observasi maupun wawancara dalam bentuk deskriptif-kualitatif yakni metode penelitian yang menghasilkan data deskriptif yang menggambarkan suatu objek keadaan yang terjadi di lapangan.

4. Konklusi

Proses ini dilakukan untuk menarik kesimpulan terhadap data-data yang telah diolah sehingga mampu menjawab masalah terkait objek penelitian yang dilakukan oleh penulis.

\section{HASIL DAN PEMBAHASAN}

A. Sistem Pengelolaan Wakaf Produktif Tanah Sawah di Yayasan Islam Pondok Pesantren Miftahul Jannah Jatibaru Kecamatan Jatisari Karawang.

Pengelolaan wakaf produktif secara professional dan modern dapat dilihat pada aspek pengelolaan operasional harta wakaf, dalam istilah management dikatakan bahwa yang disebut dengan pengelolaan operasional adalah proses pengambilan keputusan berkenaan dengan fungsi operasi, yang menentukan hasil tidaknya seluruh rangkaian program kerja yang dapat menghasilkan produk. Dalam pengelolaan wakaf yang mengelola operasional adalah kelembagaan nadzir. (Kementerian Agama RI, 2013)

Kelembagaan nadzir yang mengelola wakaf tanah sawah di pondok pesantren Miftahul Jannah adalah pengurus Yayasan Islam Pondok Pesantren Miftahul Jannah, walaupun dalam AIW yang dikeluarkan oleh PPAIW tercantum nama perorangan. (Kementerian Agama RI, 2013)

Adapun tugas kelembagaan nadzir dalam menjalankan sistem pengelolaan wakaf sesuai dengan Undang-Undang wakaf nomor 41 tahun 2004, adalah melakukan pengadministrasian 


\section{EKSISBANK Vol. 4 No. 1 Juni 2020}

harta benda wakaf, mengelola dan mengembangkan harta benda wakaf sesuai dengan tujuan, fungsi serta peruntukannya, mengawasi dan melindungi harta benda wakaf, melaporkan pelaksanaan tugas kepada BWI. (Aden Rosadi, 2019)

Berdasarkan hasil wawancara dan melihat dokumen yang ada pengelola wakaf (nadzir) yang tertulis dalam AIW adalah nama perorangan namun dalam pelaksanaan pengelolaan wakaf tersebut dikelola oleh Yayasan Islam Pondok Pesantren Miftahul Jannah sesuai amanat dari pendiri pondok pesantren Miftahul Jannah yaitu K.H. Jejen Nasirul Hajjin. Pengadministrasian harta benda wakaf dalam rangka pengamanan aset wakaf di Yayasan Islam Pondok Pesantren Miftahul Jannah sudah baik walaupun masih ada satu bidang wakaf tanah sawah yang belum diurus Akta Ikrar Wakafnya ke PPAIW dikarenakan kendala kepemilikan tanah wakaf tersebut masih bergabung dengan tanah yang lain atau belum terpisah, tapi ada bukti berupa ikrar wakaf dari wakif.

Tanah wakaf yang dikelola oleh Yayasan yang berupa tanah darat merupakan tanah wakaf dari H. Harun Arrasyid Bin H. Sujai yang diwakaf kan pada tahun 1984, sebagai pengelola wakaf (Nadzir) adalah K.H. Jejen Nasirul Hajin adapun peruntukan dari wakaf tersebut adalah untuk pondok pesantren Miftahul Jannah dengan luas 4250 M2, pada waktu wakif mewakafkan tanahnya pada tahun 1984 belum tercatat di Pejabat Pembuat Akta Ikrar Wakaf (PPAIW). (Kanwil Jabar, 2010)

Tanah wakaf tersebut baru di catat di PPAIW Kecamatan Jatisari Kabupaten Karawang pada Tahun 2012 dengan nama wakif di atas namakan salah seorang ahli warisnya yang bernama Pahrudin Bin H. Harun Arrasyid, yang menjadi ketua nadzir adalah H. Cecep Mahmud S.Pd.I dengan nomor AIW : W2A/BA.03.2/ 574/I/2012 tanggal 16 Januari 2012 dengan luas tanah 4250 M2 dengan bukti kepemilikan AJB Nomor : 541/1979 diperuntukan untuk pondok pesantren Miftahul Jannah yang beralamat Kp. Karajan Rt. 01/02 Ds. Jatibaru Kecamatan Jatisari. Diatas tanah wakaf tersebut sebagian di gunakan untuk bangunan pondok pesantren Miftahul Jannah dan sebagian lagi ada tanah kosong dan kolam ikan.

Selain mengelola wakaf yang berupa tanah darat Yayasan Islam Pondok Pesantren Miftahul Jannah juga mengelola wakaf berupa tanah sawah yang berada di empat lokasi yaitu:(Kementerian Agama RI, 2013)

1) Tanah wakaf sawah yang diwakafkan oleh wakif yang bernama Hajah Rohamah Binti Masud, yang menjadi ketua nadzir yaitu $\mathrm{H}$. Jejen Nasirul Hajjin, di wakafkan Tahun 2006, tanah wakaf tersebut tercatat di PPAIW Kecamatan Jatisari Kabupaten karawang tanggal 19 September 2006 dengan Nomor : w.2a/BA.03.2 /548/IX/2006, dengan luas tanah $3.550 \mathrm{M} 2$ yang berlokasi di Karajan Rt. 01/02 Desa Jatibaru Kecamatan Jatisari diperuntukan untuk kesejahteraan pondok pesantren Miftahul Jannah.

2) Tanah wakaf sawah yang diwakafkan oleh wakif yang bernama $\mathrm{H}$. Koyub Bin Abdul Majid di wakafkan Tahun 1991 yang menjadi ketua nadzir yaitu H. Jejen, tanah wakaf tersebut tercatat di PPAIW Kecamatan Jatisari Kabupaten Karawang tanggal 10 September 1991 dengan Nomor : w.2a/06/265/Tahun 1991, dengan luas tanah 3.550 M2 yang berlokasi di Kepuh 3 Desa Jatibaru Kecamatan Jatisari diperuntukan untuk pondok pesantren Miftahul Jannah.

3) Tanah wakaf yang diwakafkan oleh wakif yang bernam Abdul Jamil diwakafkan pada tahun 1993 yang menjadi ketua nadzir yaitu H. Jejen Nasirul Hajjin dengan luas tanah 3.550 M2 diperuntukan untuk pondok pesantren Miftahul Jannah. Tanah wakaf tersebut baru di catat di PPAIW Kecamatan Jatisari Kabupaten Karawang pada Tahun 2015 dengan nama wakif Abdul Jamil, yang menjadi ketua nadzir yaitu $H$. Ade Rosi Fauzan dengan nomor AIW : 09/w.2a/BA.03.2/07/2015 tanggal 16 Juli 2015 dengan luas tanah 3.550 M2 diperuntukan untuk kesejahteraan pondok pesantren Miftahul Jannah.

4) Tanah wakaf sawah yang diwakafkan oleh wakif yang bernama $\mathrm{Hj}$. Rukoyah yang 


\section{EKSISBANK Vol. 4 No. 1 Juni 2020}

ditunjuk sebagai nadzir yaitu H. Ade Rosi Fauzan di wakafkan pada tahun 2016 dengan luas tanah 3550 M2 Bukti kepemilikan tanah wakaf ini berupa berupa ikrar wakaf dari wakif dan belum diurus surat-surat wakafnya ke PPAIW dikarenakan terkendala dengan surat kepemilikan yang masih bergabung belum terpisah. yang berlokasi di Desa Sukahaji Kecamatan Ciasem Kabupaten Subang diperuntukan untuk pondok pesantren Miftahul Jannah. (Sugiyono, 2016)

Pengelolaa wakaf produktif tanah sawah di Yayasan Islam Pondok Pesantren Miftahul Jannah dengan cara disewakan dan dalam penentuan penyewaannya menggunakan cara sewa pertahun, dalam prinsip pembayarannya secara langsung atau tunai untuk jangka waktu satu tahun, penentuan penyewa dilakukan dengan cara menawarkan kepada orang yang di kenal oleh kepengurusan nadzir adapun bukti penyewaannya adalah berupa kwitansi.

Model pembiayaan baru untuk proyek wakaf produktif secara institusional pengelolaan wakaf yang ada di Yayasan Islam Pondok Pesantren Miftahul Jannah adalah model sewa berjangka panjang dan $H u k r$, dimana manajemen berada di tangan lembaga pembiayaan yang menyewa harta wakaf untuk periode jangka waktu panjang. Penyedia dana mengambil tanggung jawab kontruksi dan menejemen serta membayar sewa secara periodik kepada pengelola harta wakaf. Dalam model $H u k r$, suatu ketentuan ditambahkan dalam kontrak atas dasar mana lembaga pembiayaan memberikan suatu pembayaran lump sum tunai.(Kanwil Jabar, 2010) Perkembangan penyewaan wakaf tanah sawah di Yayasan Islam Pondok Pesantren Miftahul Jannah mengalami peningkatan dari tahun ketahun, ini adalah salah satu bukti bahwa pengelolaan wakaf tanah sawah yang cukup efektif dan peran pengelola wakaf Yayasan Islam Pondok Pesantren Miftahul Jannah kelihatan hasilnya. Walaupun masih ada kekurangnnya yaitu alat bukti penyewaan yang hanya berupa kwitansi bukan berupa berita acara penyewaan yang tertulis yang didalamnya memuat kesepakatan antara penyewa dan pengelola wakaf.
Pengawasan dan perlindungan pelaksanaan kesepakatan sewa menyewa antara nadzir dan penyewa, pengelola wakaf akan mencari informasi dari warga sekitar lokasi tanah wakaf untuk memastikan apakah sawah dikelola sesuai syariat islam atau tidak. Pengelola akan menghubungi pihak penyewa dua bulan sebelum habis tanggal akad sewa, apakahakan di teruskan atau tidak. Apabila pihak penyewa memutuskan untuk tidak menyewa lagi maka pihak pengelola wakaf akan mencari penyewa yang baru diusahakan dengan harga yang sama atau lebih.

Pengelola wakaf belum pernah melaporkan pengelolaan wakaf kepada pihak pemerintah atau pihak terkait dikarenakan tidak mengerti jalur atau tata cara pelaporannya juga tidak ada perintah dari KUA untuk melakukan pelaporan pengelolaan wakaf. Adapun pelaporan pengelolaan wakaf diumumkan di intern pengurus dalam pelaksanaan rapat tahunan. (Sugiyono, 2016)

Didalam pola pengelolaan wakaf di Indonesia ada dua paradigma yang pertama, paradigma lama terhadap pengelolaan wakaf, pengelolaan wakaf menekankan pada pentingnya pelestarian dan keabadian benda wakaf, paradigma ini menggunakan management tradisionalis konsumtif. Yang ke dua paradigma baru pengelolaan wakaf menekankan pada pemanfaatan yang lebih nyata tanpa kehilangan eksistensi benda wakaf, management yang dipakai pada paradigma ini yaitu professional produktif. (Sugiyono, 2016)

Berdasarkan hasil penelitian pengelolaan wakaf produktif tanah sawah di Yayasan Islam Pondok Pesantren Miftahul Jannah dalam pola pengelolaannya masih masih termasuk dalam pola pengelolaan wakaf tradisional konsumtif dimana ditandai dengan rekrutmen SDM nadzir wakaf berdasarkan aspek ketokohan bukan dari kemampuan dalam mengelola, pemanfaatan hasil wakaf masih bersifat konsumtif kurang dirasakan manfaatnya oleh masyarakat, kontrol dan pertanggung jawaban yang lemah.

B. Penyaluran Hasil Wakaf Produktif Tanah Sawah di Yayasan Islam Pondok Pesantren 


\section{EKSISBANK Vol. 4 No. 1 Juni 2020}

Miftahul Jannah Jatibaru Kecamatan Jatisari

Karawang.

Hasil dari pengelolaan wakaf tanah sawah di Yayasan Islam Pondok Pesantren Miftahul Jannah dalam peruntukannya digunakan untuk operasional pondok pesantren dan untuk perbaikan atau renovasi ringan di pondok pesantren, dengan pembagian 50\% untuk perbaikan atau renovasi ringan pondok pesantren dan 50\% untuk biaya operasional pondok pesantren. Aloksi anggaran operasional diperuntukan $75 \%$ untuk honor dewan guru dan 25\% untuk kebutuhan ATK (Alat Tulis Kantor). (Sugiyono, 2016)

Yang termasuk kedalam perbaikan atau renovasi ringan adalah pengecetan, perbaikan bangku, perbaikan tempat tidur santri, perbaikan asrama santri, perbaikan masjid pesantren dari mulai sound system sampai dengan bangunan masjid dan perbaikan kamar mandi santri.

Pemberian honor dari hasil pengelolaan wakaf tanah sawah kepada dewan guru diberikan satu tahun sekali setelah menerima hasil sewa wakaf tanah sawah dari penyewa. (Sugiyono, 2016)

Wakaf bertujuan memanfaatkan harta benda wakaf sesuai dengan fungsinya, wakaf berfungsi mewujudkan potensi dan manfaat ekonomis harta benda wakaf untuk kepentingan ibadah dan untuk memajukan kesejahteraan umat. (Sugiyono, 2017)

Dalam pengelolaan dan pengembangan harta benda wakaf nadzir wajib mengelola dan mengembangkan harta benda wakaf sesuai dengan peruntukan yang tercantum dalam AIW (Akta Ikrar Wakaf). (Sugiyono, 2016)

Penyaluran hasil wakaf produktif tanah sawah yang ada di Yayasan Islam Pondok Pesantren Miftahul Jannah telah sesuai dengan peraturan perundang-undangan dimana dalam Akta Ikrar Wakaf tercantum peruntukan dari wakaf tanah sawah tersebut adalah untuk kesejahteraan pondok pesantren Miftahul Jannah.

Dampak dari pengelolaan wakaf produktif tanah sawah di Yayasan Islam Pondok Pesantren Miftahul Jannah cukup membantu pondok pesanten dalam pelaksanaan pendidikan untuk mencukupi biaya operasional dan perbaikan sarana pondok pesantren walaupun tidak mencukupi sepenuhnya, untuk mencukupi kekurannya dibantu dengan iuran bulan santri, bantuan dari masyarat dan dari pemerintah. (Sugiyono, 2017)

Pengelolaan wakaf produktif tanah sawah di Yayasan Islam Pondok Pesantren Miftahul Jannah belum berdampak langsung terhadap masyarakat sekitar pondok pesantren, bisa dilihat dari peruntukan hasil pengelolaan tanah wakaf tersebut yang hanya peruntukan untuk operasional pondok pesantren dan untuk perbaikan atau renovasi ringan di pondok pesantren tidak ada peruntukan yang berkaitan dengan kepentingan langsung dengan masyarakat. Hal ini dikarenakan pengelolaan wakaf tanah sawah yang sedikit dan hasil sewa yang hanya cukup untuk membantu operasional pesantren. Dalam program pendidikan pondok pesantren miftahul jannah memberikan keringanan biaya kepada masyarakat sekitar yang mau belajar atau mondok di pondok pesantren Miftahul Jannah.

\section{PENUTUP}

\section{A. Kesimpulan}

Nadzir dalam mengelola wakaf tanah sawah dengan cara disewakan dan dalam penentuan penyewaannya menggunakan cara sewa pertahun (model sewa jangka panjang dan $h u k r$ ). Untuk mengawasi dan melindungi pelaksanaan kesepakatan sewa menyewa antara nadzir dan penyewa, pengelola wakaf akan mencari informasi dari warga sekitar lokasi tanah wakaf untuk memastikan apakah sawah di kelola sesuai syariat islam atau tidak. Pengelola wakaf belum pernah melaporkan pengelolaan wakaf kepada pihak pemerintah atau pihak terkait dikarenakan tidak mengerti jalur atau tata cara pelaporannya. pengelolaan wakaf produktif tanah sawah di Yayasan Islam Pondok Pesantren Miftahul Jannah dalam pola pengelolaannya masih masih termasuk dalam pola pengelolaan wakaf tradisional konsumtif.

Hasil dari pengelolaan wakaf tanah sawah di Yayasan Islam Pondok Pesantren Miftahul Jannah di peruntukan untuk operasional pondok pesantren dan untuk perbaikan atau renovasi ringan di pondok pesantren, dengan pembagian 


\section{EKSISBANK Vol. 4 No. 1 Juni 2020}

$50 \%$ untuk perbaikan atau renovasi ringan pondok pesantren dan 50\% untuk biaya operasional pondok pesantren. Adapun pembagian biaya operasional pondok pesantren diperuntukan untuk $75 \%$ untuk honor dewan guru dan 25\% untuk kebutuhan ATK (Alat Tulis Kantor). Dari hasil pengelolaan wakaf tanah sawah memiliki dampak dalam pelaksanaan pendidikan untuk mencukupi biaya operasional dan perbaikan sarana pondok pesantren walaupun tidak mencukupi sepenuhnya. Dalam pengelolaan wakaf ini belum berdampak langsung terhadap masyarakat sekitar pondok pesantren hanya memberikan keringanan biaya kepada masyarakat sekitar yang mau belajar atau mondok di pondok pesantren Miftahul Jannah.

\section{B. Saran}

Berdasarkan hasil penelitian, beberapa saran yang dapat di terapkan adalah sebagai berikut :

1) Pemilihan nadzir atau pengelola tanah wakaf agar benar-benar orang yang mengerti tentang management tidak berdasarkan atas aspek ketokohan.

2) Pengamanan aset tanah wakaf untuk segera dibuatkan AIW (Akta Ikrar Wakaf) supaya tanah wakaf itu tidak ada yang menggugat dikemudian hari.

3) Mendapatkan hasil yang optimal dalam pengelolaan tanah sawah dapat dikelola sendiri oleh nadzir.

\section{Rekomendasi}

Berdasarkan dari hasil penelitian di atas, peneliti memberikan beberapa rekomendasi bagi penelitian selanjutnya, untuk mengkaji lebih luas dan lebih dalam lagi tidak hanya meneliti wakaf tanah sawah melaikan bisa meneliti wakaf tanah darat yang ada di Yayasan Islam Pondok Pesantren Miftahul Jannah Jatibaru Kecamatan Jatisari Karawang.

\section{DAFTAR PUSTAKA}

Aden Rosadi. (2019). Zakat dan Wakaf. Simbiosa.

Departemen Agama. (2005). Undang-Undang No. 41 Tahun 2004. Dirjen Bimas Islam.

Departemen Agama RI. (1992). Kompilasi Hukum Islam di Indonesia. Dirjen Pembinaan Kelembagaan Islam.

Farid Wadjdy dan Mursyid. (2007). Wakaf Dan Kesejahteraan Umat. Pustaka Pelajar.

K.H. Ade Rosi Fauzan. (2019). Wawancara Luas Tanah wakaf Di Yayasan Islam Pondok Pesantren Miftahul Jannah Jatibaru Kecamatan Jatisari Karawang.

Kanwil Jabar. (2010). Klasifikasi Tanah Wakaf di Jawa Barat. Penyelenggara haji, zakat dan wakaf.

Kementerian Agama RI. (2013). Pedoman Pengelolaan dan Perkembangan Wakaf. Dirjen Bimbingan Masyarakat Islam direktorat Pemberdayaan Wakaf.

Mundzir Qahaf. (2005). Manajeman wakaf produktif. PT Khalifa.

Sugiyono. (2016). Metodologi Penelitian Kuantitatif, Kualitatif dan $R \& D$. Alfabeta. Sugiyono. (2017). Metode Penelitian Kuantitatif, Kualitatif, dan $R \& D$. Alfabeta. 